\title{
Inventarisasi Jenis Burung di Areal Bekas Tambang Batubara PT Pilar Putra Sejati Kelurahan Loa Bakung Kecamatan Sungai Kunjang Samarinda
}

\author{
M. Masrudy* \\ Pengelolaan Hutan, Politani, \\ Samarinda, 75131 \\ muhammadmasrudy60@gmail.com \\ *Corresponding Author
}

\author{
M. Fadjeri \\ Pengelolaan Hutan, Politani, \\ Samarinda, 75131 \\ fadjeriedris@gmail.com
}

\author{
Emi Malaysia \\ Pengelolaan Hutan, Politani, \\ Samarinda, 75131 \\ Emimalaysi4@gmail.com
}

\author{
Dwinita Aquastini \\ Pengelolaan Hutan, Politani, Samarinda, 75131 \\ Dwiniaqua@yahoo.co.id
}

\begin{abstract}
Abstrak--The purpose of this study was to determine the presence of bird species in the area of the former coal mine of PT Pilar Putra Sejati, Loa Bakung Village, Sungai Kunjang District, Samarinda.This research has been carried out for approximately three months starting from May 2021 to September 2021. The method used for observing birds is a direct method using traps or traps in the form of fog nets and traps or snares, where observations are made at six points, as follows; three points on the edge of the dug hole and three points located on trees frequented by birds. At each point, observations were held in the morning at 06.00-08.00 and in the afternoon at 16.00-18.00 WITA.The results of observations at the research location found as many as 9 species of birds from 6 families. Bird species during the study were Lonchura punctulata (Ploceidae family), Passer montanus (Ploceidae family), Streptopelia chinensis (Colombidae family), Giopelia striata (Colombidae family), Arborophila charltonii (Phasianidae family), Phynonotus aurigaster (nis family), Aenicurus family Rallidae), Acridotheres javanicus (family Sturnidae), and Lonchura fuscans (family Ploceidae).
\end{abstract}

\section{Kata Kunci : Inventory, bird family and bird species}

\section{PENDAhUluan}

Burung merupakan bagian dari masyarakat hutan yang memiliki peranan penting bagi kelangsungan dan kelestarian hutan. Burung memegang peranan bagi regenerasi hutan, baik sebagai penyebar biji, penyerbuk tanaman, maupun sebagai control terhadap populasi serangga (Alikodra dkk, 1988).

Suatu kawasan tertentu dapat saja memiliki keanekaragaman yang tinggi akan jenis burung, tetapi ada pula kawasan lain yang hanya mempunyai keanekaragaman jenis burung yang rendah, misalnya pada kawasan hutan keanekaragaman jenisnya akan lebih besar bila dibandingkan dengan kawasan perkotaan. Begitu pula dengan areal hutan yang masih murni memiliki jenis burung yang lebih beragam dari pada areal hutan yang sudah memiliki perubahan akibat beberapa sebab seperti penebangan dan kebakaran (Kuspriyanti, 1990).

Keberadaan jenis burung sangat didukung oleh kondisi iklim yang baik dan keragaman jenis tumbuhan sebagai sumber pakan dan tempat mereka untuk berkembang biak. Burung merupakan salah satu satwa yang memiliki habitat yang khas. Satu habitat dapat dicirikan oleh jenis burung tertentu yang hidup di dalamnya. Begitu juga sebaliknya, satu jenis burung dapat menjadi penciri habitat tertentu.

Menurut Balen (1989), perubahan habitat yang terjadi dapat cukup jelas ditentukan oleh perubahan keanekaragaman jenis burung setempat. Oleh karena itulah burung dapat dimanfaatkan sebagai petunjuk biologi (bio-indikator) untuk menentukan suatu tingkat pencemaran atau tingkat kerusakan suatu lingkungan. Perubahan habitat yang ekstrim dapat berakibat pada perubahan populasi atau keanekaragaman burung penghuninya atau mendukung terjadinya perpindahan burung yang ada ketempat lain ataupun mengalami kematian. Tetapi ada pula beberapa jenis burung yang mampu kembali setelah terjadi bencana besar, seperti setelah kebakaran hutan ataupun gangguan lainnya. Bahkan beberapa jenis diantara mereka mampu berkembang biak dan menjadi jenis yang dominan pada habitat yang telah berubah tersebut (Boer, 1994).

\section{METODOLOGI}

\section{A. Tempat dan Waktu}

Penelitian dilaksanakan pada bulan Mei 2021 s/d. bulan September 2021. Lokasi penelitian yaitu di area Bekas Tambang Batubara PT Pilar Putra Sejati, Kelurahan Loa Bakung, Kecamatan Sungai Kunjang, 
Samarinda. dan dilanjutkan di Laboratorium Konservasi Politeknik Pertanian Negeri Samarinda.

\section{B. Bahan dan Alat}

1. Bahan

Bahan yang digunakan dalam penelitian ini adalah burung-burung yang ada pada areal penelitian.

2. Alat

a. Teropong, digunakan untuk memperjelas penglihatan terhadap burung yang di amati

b. Kamera, digunakan untuk mengambil gambar burung

c. Parang, digunakan untuk membersihkan tempat pengamatan

d. Perangkap atau jebakan, digunakan untuk menangkap burung

e. Alat tulis menulis, untuk mencatat data.

\section{Prosedur Penelitian}

1. Orientasi lapangan untuk mengetahui keadaan lapangan.

2. Penelitian ini dilaksanakan dengan cara pengamatan pada titik-titik yang telah di tentukan.

3. Mengamati, mencatat dan mendokumentasikan jenis burung yang datang ke pohon atau permukaan tanah pada pagi (jam $06.00 \mathrm{~s} / \mathrm{d}$. jam 08.00) dan sore (jam 16 s/d. jam 18.00).

4. Perangkap atau jebakan, digunakan untuk menangkap burung, sbb;

a. Aktipitas burung sehari-hari yang berada di pohon dengan menggunakan alat jala kabut.

b. Aktipitas burung sehari-hari di permukaan tanah dengan menggunakan alat jebakan atau jerat.

5. Mengindentifikasi jenis burung yang belum diketahui dengan cara melihat dan menyamakan dengan literature yang ada.

6. Burung yang telah diidentifikasi, dicatat dalam Tally Sheet pengamatan burung seperti pada Tabel 1.

Tabel 1. Tally Sheet Pengamatan Burung.

\begin{tabular}{|l|l|l|l|}
\hline No. & Jenis & Famili & Keterangan \\
\hline. & & & \\
\hline. & & & \\
\hline. & & & \\
\hline n. & & & \\
\hline
\end{tabular}

\section{Pengolahan Data}

Mengindentifikasi jenis burung yang belum diketahui dengan cara membandingkan dengan buku Mackinnon dkk. (1992), dan apabila ada jenis yang belum di ketahui, maka dicatat ciri-ciri dan di bawah ke Laboratorium Konservasi Politani

\section{HASIL DAN PEMBAHASAN}

Hasil pengamatan di lapangan pada bekas tambang batubara PT Pilar Putra Sejati, Kelurahan Loa Bakung,
Kecamatan Sungai Kunjang, Samarinda dan diteruskan di laboratorium Konservasi Politani untuk diidentifikasi jenis-jenis burung seperti yang ditampilkan pada Tabel 2 di bawah ini :

Tabel 2. Jenis-jenis Burung yang Terdapat di Bekas Tambang Batubara PT Pilar Putra Sejati, Kelurahan Loa Bakung, Kecamatan Sungai Kunjang, Samarinda.

\begin{tabular}{|c|l|l|}
\hline No. & \multicolumn{1}{|c|}{ Jenis } & \multicolumn{1}{|c|}{ Famili } \\
\hline 1. & $\begin{array}{l}\text { Pipit / Bondol Peking } \\
\text { (Lonchura punctulata) }\end{array}$ & Ploceidae \\
\hline 2. & $\begin{array}{l}\text { Gereja Erasia (Passer } \\
\text { montanus) }\end{array}$ & Ploceidae \\
\hline 3. & $\begin{array}{l}\text { Tekukur Biasa (Streptopelia } \\
\text { chinensis) }\end{array}$ & Colombidae \\
\hline 4. & $\begin{array}{l}\text { Perkutut Jawa (Giopelia } \\
\text { striata) }\end{array}$ & Colombidae \\
\hline 5. & $\begin{array}{l}\text { Puyuh-gonggong Kalung } \\
\text { (Arborophila charltonii) }\end{array}$ & Phasianidae \\
\hline 6. & $\begin{array}{l}\text { Cucak Kutilang (Phynonotus } \\
\text { aurigaster) }\end{array}$ & Pycnonotidae \\
\hline 7. & $\begin{array}{l}\text { Kareo Padi / Burak-burak } \\
\text { (Amaurornis phoenicurus) }\end{array}$ & Rallidae \\
\hline 8. & $\begin{array}{l}\text { Kerak Kerbau / Jalak Kebo } \\
\text { (Acridotheres javanicus) }\end{array}$ & Sturnidae \\
\hline 9. & $\begin{array}{l}\text { Pipit / Bondol Kalimantan } \\
\text { (Lonchura fuscans) }\end{array}$ & Ploceidae \\
\hline
\end{tabular}

Berdasarkan Tabel 2 di atas. Pada penelitian ini ditemukan 6 famili dan 9 jenis burung yaitu pertama (1) famili Ploceidae yang terdiri dari tiga (3) jenis burung: Pipit / Bondol Peking (Lonchura punctulata), Gereja Erasia (Passer montanus) dan Pipit / Bondol Kalimantan (Lonchura fuscans); kedua (2) famili Colombidae yang terdiri dari dua (2) jenis burung yaitU: Tekukur Biasa (Streptopelia chinensis) dan Perkutut Jawa (Giopelia striata); ketiga (3) famili Phasianidae terdiri sari satu (1) jenis burung yaitu Puyuh-gonggong Kalung (Arborophila charltonii); keempat (4) famill Pycnonotidae terdiri sari satu (1) jenis burung yaitu Cucak Kutilang (Phynonotus aurigaster); Kelima (5) famili Rallidae terdiri sari satu (1) jenis burung yaitu Kareo Padi / Burak-burak (Amaurornis phoenicurus) dan yang keenam (6) famili Sturnidae terdiri sari satu (1) jenis burung yaitu Kerak Kerbau / Jalak Kebo (Acridotheres javanicus).

Mackinnon dkk. (1992), Famili Ploceidae merupakan famili yang sangat besar, tersebar di Australia, Asia dan Eropa. Suku ini berukuran kecil, ekor pendek, paruh tebal pendek berguna untuk memakan biji. Sarang berbentuk bola dan tertutup. Senang berkelompok dan membentuk gerombolan yang besar. Kebiasaan dan kesenangannya memakan biji-bijian menjadikan suku ini hama yang sangat berbahaya dalam pertanian.

Famili Colombidae tersebar sangat luas di dunia. Makanan utamanya buah-buahan dan biji-bijian. Hampir semua jenis memiliki tubuh yang padat, gemuk dengan paruh yang pendek tetapi kuat. Sarang terbuat dari ranting-ranting yang tampak rapuh, tempat meletakkan 
telurnya. Kicauan berupa suara berirama yang diulangulang. Ketika terbang kepakkan sayapnya berbunyi khas.

Famili Phasianidae tersebar luas di seluruh dunia, hidup di permukaan tanah. Bersarang di tanah tetapi tidur di pohon. Beberapa jenis mempunyai suara nyaring bersih. Banyak jenis yang menggunakan sayap untuk membuat bunyi mendengung atau menunjukkan gerakan bergoyang.

Menurut Mackinnon dkk. (1992), famili Pycnonotidae adalah burung cucak-cucakan merupakan burung pemakan buah-buahan, walaupun mereka juga memakan serangga. Merupakan burung yang penuh percaya diri, dengan kicauan yang ramai dan sangat musical pada beberapa jenis. Cenderung hidup di pohon dan membuat sarang berbentuk mangkuk yang tidak rapi.

Famili Rallidae dikenal sebagai burung mandar, mandar padi dan koreo. Sangat menarik dengan berbagai ragam corak dan warna, memiliki sifat yang sangat sensitive terhadap suara dan gerakan yang sangat gesit. Memiliki variasi makanan yang sangat beragam terdiri dari atas invertebrata (cacing dan molucca), biji-bijian, bagian tumbuhan seperti akar, tunas dan daun,b eras, jagung, buah bahkan sisa makanan manusia.

Famili Sturnidae gagah dengan paruh kuat, tajam, lurus dan tungkai kaki panjang. Pemakan buah-buahan dan invertebrate. Kebanyakan bersarang di lubang pohon. Suka rebut, berceloteh dengan suara yang keras atau menirukan suara burung lain.

\section{Kesimpulan}

Burung yang ditemukan selama pengamatan sebanyak 9 jenis yaitu: Lonchura punctulata, Passer montanus, Streptopelia chinensis, Giopelia striata, Arborophila charltonii, Phynonotus aurigaster, Amaurornis phoenicurus, Acridotheres javanicus, dan Lonchura fuscans. Ditemukan 6 Famili yaitu: Ploceidae, Colombidae, Phasianidae, Pycnonotidae, Rallidae dan Sturnidae. Mengingat waktu penelitian yang cukup singkat, maka perlu dilakukan penelitian lebih lanjut dengan waktu yang lebih lama untuk mengetahui jenis burung.

\section{DAFTAR PUSTAKA}

Alikodra (1988). Pengelolaan Satwa Liar Jilid 1. Direktur Jendral Pendidikan Tinggi Pusat Antar Universitas. Bogor.

Anonim. (1994). Pedoman Teknis Inventarisasi Satwaliar. Badan Penelitian dan Pengembangan Kehutanan Departemen Kehutanan, Jakarta.

Anonim.(2013).http://Balaiedukasi.blogspot.com/2013/11 /Penyesuaian-Makhluk-Hidup-dengan.html

Balen, S. (1987). Pedoman untuk Pemanfaatan dan Sensus Burung di Gunung Papandayan. Kursus Analisa Dampak Lingkungan. Angkatan V. Bogor.
Bismark, M. (1986). Keragaman Burung di Hutan Bakau. Taman Nasional Kutai Kalimantan Timur. Buletin Penelitian. $482: 11-12$.

Boer, C. (1989). Keragaman Jenis Burung di Hutan Lindung Bukit Soeharto dan Hutan Taman Industry. PT ITCI Kenanga, Balikpapan, Kalimantan Timur.

Hernowo, J.B. (1989). Konsepsi Ruang Terbuka Hijau di Kota Sebagai Pendukung Pelestarian Burung.

Mackinnon, J., K. Phillipps dan B.V. Balen. (1992). Burung-Burung di Sumatera, Jawa, Bali dan Kalimantan.

Morrison, M.L., B.G. Marcot and R.W. Mannan. (1992). Wildlife-Habitat Relationship: Consepts and Applications. The University of Wisconsisn Press. Madison, Wisconsin.

Magurran, A.E. (1988). Ecological Diversity and Its Measurement. Princeton University Press. New. Jersey.

Kuspriyanti, E. (1990). Studi Keanekaragaman Jenis Burung di Lingkungan Kampus Universitas Mulawarman, Gunung Kelua Skripsi Fakultas Kehutanan. Universitas Mulawarman; Samarinda.

Sujatnika, P.J., T.R. Soehartono, M.J. Crosby dan A. Mardiastuti. (1995). Melestarikan Keanekaragaman Hayati Indonesia: Pendekatan Daerah Burung Endemik (Conserving Indonesian Biodiversity: The Endemic Area Approach). Jakarta: PHPA \& BirdLife International-Indonesia Programme.

Susilo, A. (1989). Keanekaragaman Jenis Burung pada Hutan Bekas Tebangan di Mentoko Taman Nasional Kutai. Kalimantan Timur. Winatrop Vol. 4. NO. 2 